\title{
Enhancement of Waterproofing Properties of Finished Upper Leather Produced from Bangladeshi Cow Hides
}

\author{
Abrar Shahriar, Fatema-Tuj-Zohra, A. B. M. Wahid Murad and Sobur Ahmed
}

\begin{abstract}
Waterproofness property of leather can be enhanced by modifying different steps involved in pre-tanning to finishing operations. In this study three sets of experiment were conducted where tanning and finishing techniques differed to analyze the improvement of the waterproofness property. Use of surfactants and hydrophilic agents were avoided to improve this property. Moreover, different waterproof fatliquors were used and changing of the finishes in each experiment was performed to improve and evaluate the waterproofness of leathers. Waterproofness and other physical characteristic properties were assessed following standard methods. Leather samples of experiment-3 where extensive finishing was done, showed the best result of waterproofness which is significantly higher than the minimum requirement of shoe upper leather. All other physical properties except water vapour permeability of leather samples of experiment-3 were excellent as compared to other experiments. Scanning Electron Microscopy (SEM) image of the leather sample was also analyzed.
\end{abstract}

Index Terms-Waterproofness, Surfactants, Retanning, Fatliquoring, Finishing.

\section{INTRODUCTION}

Leather is the second export earning sector next to readymade garments in Bangladesh. Leather products confer high aesthetic value as well as functional and social value as a commodity. Because of high thermal conductivity of leather goods such as garments, gloves and shoe uppers are of maximum utility of cold humid countries and therefore unless these leathers are highly hydrophobic, they are not of much use [1]. Furthermore, leather which has absorbed too much water loses its ability to insulate against heat and cold [2]. Uptake of water by waterproof leathers which are used for footwear should not be more than $25-30 \%$ [3]. However, additional water vapour permeability and reversible water-uptake of some degree to remove perspiration from body should be allowed by the leather. Therefore, almost all types of leathers, except a few (like chamois), are made waterproof to varying degrees. In order to prevent the wetting of leather, it is necessary to be aware of the process of leather wetting. Generally, it takes place in four-steps [3]:

Published on July 25, 2019.

Abrar Shahriar is with Department of Leather Engineering, Institute of Leather Engineering and Technology, University of Dhaka

Fatema-Tuj-Zohra is an Assistant Professor, Department of Leather Products Engineering, Institute of Leather Engineering and Technology, University of Dhaka

A. B. M. Wahid Murad is with Department of Leather Engineering, Institute of Leather Engineering and Technology, University of Dhaka

Sobur Ahmed is an Associate Professor, Department of Leather Engineering, Institute of Leather Engineering and Technology, University of Dhaka (email: soburahmed@du.ac.bd, soburahmed2001@yahoo.com) i) Water spreads over and wets the leather surface;

ii) Water penetrates into the leather;

iii) Water wets the fibre network (i.e. internal surface of leather);

iv) The leather soaks by water due to the attractive interaction between water and leather network.

Apart from collagen backbone, there might be some degree of involvement of tanning agents, dye molecules, salts, and other materials in these interactions.

The chain of process steps must be interrupted to prevent the wetting of leather and to make the leather waterproof. There are many polar functional groups in collagen fibers such as $-\mathrm{OH},-\mathrm{COOH},-\mathrm{NH}_{2}$ and $-\mathrm{CONH}-$. The chemical compounds to be added mostly are hydrophilic and have good water affinity. Therefore, to improve water resistance property several leather making processes and leather surface modifications are applied [3][4][5]:

1. Sealing the leather with an impermeable layer, i.e. a heavy polymer finish. A foil or thin laminate of waterproof synthetic material can be attached to the surface of the leather by adhesive, also [6]. The film prevents spreading of water; as a result, the leather cannot be wetted under static condition. However, the water vapour permeability drastically reduced by such film even it produced using most modern technologies [6][7].

2. Closed waterproofing-closing the spaces between the leather fibers with water-repellent substances [4][5]. It might be achieved in two different ways: firstly, leather impregnation by incorporation of water-insoluble substances, for example, solid fats, and molten waxes; secondly, using hydrophilic waterproofing [8]. Grease impregnation is a long-established system, and gives a special look and feel to the leather. However, the filling of the gaps with grease prevents the penetration of water into the fibre network, but the leather becomes extremely heavy and completely blocks any air and water vapour permeability. In the second case waterproofing of leather is achieved by application of certain surfactants (e.g. hydroxycarboxylic acid derivatives, alkenyl-succinic acid derivatives, hydroxyethylation fatty acid, etc.), which bind to the leather and can absorb a certain quantity of water [9]. The problem with closed waterproofing is that it (partially) seals the pores and, therefore, frequently impairs the water vapour permeability and water vapour absorption of the leather.

3. Open waterproofing- creating a hydrophobic net around the fibers without filling spaces- is smartest approach to make waterproof leather [3][4][5]. The fibers and fibrils are bind through its functional groups and forms hydrophobic layer by using low surface energy (less than $30 \mathrm{mN} / \mathrm{m}$ ) waterproof agent. Water vapour can penetrate 
into the fibre network, while water droplets possess high surface tension and cannot spread over the hydrophilic fibre and wet the internal surface. Wettability with water are reduced or almost completely eliminated through increasing the interfacial tension between leather fibers and water by depositing water repellents in the leather substance.

There are many other factors that influence the waterproofness of leather not only chemical substances used in leather manufacture (salts, tensides, tanning agents, retanning agents, dyestuffs, fatliquoring agents and finishing agents). Both initial quality of skin or hide and each operation involved in producing the finished leather have significant influence on the waterproofness degree of finished leather [10][11]. Leather finishing is the process where a set of operations (chemical and mechanical) are performed in a sequential manner under a system during which finishes are applied to the leather surface with the aim of improving its appearance, feel, waterproofness and general suitability to intended use. These operations deal with the art of enhancing the quality of leather so as to make it suitable for making products [12]. The final uses of different leather are wide and include shoe uppers, garments, gloves, leather goods, furniture and automotive upholstery and so on [13].

The choice of waterproofing system depends on the degree of water resistance required, the purpose of leather, and price. Extreme hydrophobicity is required for military footwear leather [14]. Waterproof leathers are commercially of high interest because these leathers are sold at a relative high price due to requirement of specialty products.

The aim of this work was to evaluate the waterproofing behaviour of the upper leather upon various combinations of pretanning, tanning, retanning, fatliquoring and finishing agents. Extensive work has been performed in this research to develop process for the production of valueadded quality waterproof finished leather using domestic cow hides.

\section{CHOICE OF CHEMICALS}

The hides and skins tanning with chromium salts (i.e. wet blue leather) induce the collagen fibre to be resistant against bacterial attack and increase resistance to temperature (Figure 1).

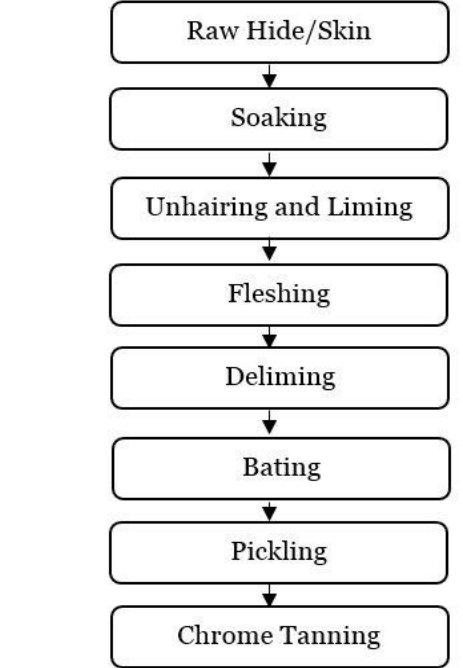

Fig. 1. Flow chart of wet blue leather production

However, this process does not possess the physical and aesthetic properties required to the products made from leather. Therefore, after chrome tanning obtained wet blue is converted to usable leather (Figure 2) in a series of chemical and mechanical operations (i.e. retanning, dyeing, fatliquoring, drying, finishing, etc.). The choice of retanning and fatliquoring chemicals depends on the desired properties (softness, touch, fullness, grain firmness or looseness, smell, adhesion properties, water uptake or release, and waterproofness) of the final leather.

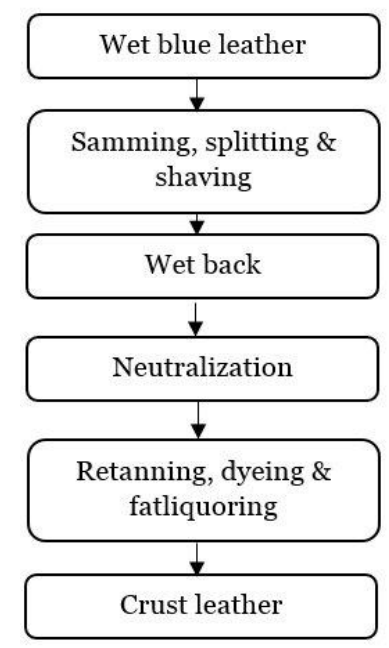

Fig. 2. Flow chart of crust leather production

Various retanning agents were developed to give the chrome tanned leather fullness with selective filling of the structure and to provide tight and uniform grain surface [9][15][16]. In general, retanning agents can be inorganic mineral substances (chrome, aluminium, zirconium salts) or organic materials (vegetable or synthetic). The synthetic retanning organic agents can be divided into three main groups: 1) syntans (condensation products of aromatic compounds like phenol, naphthalene sulphonic acid with formaldehyde or urea); 2) resins (condensation products from formaldehyde with amino and amido compounds like urea, melamine, and dicyandiamide); 3) polymers, mainly acrylic (polymerization products from acrylic acid derivatives). Syntans are better soluble in water than vegetable tannins, because they molecules are smaller. 
Therefore, vegetable tannins more difficult penetrate to leather matrix, and leather tanning process runs longer.

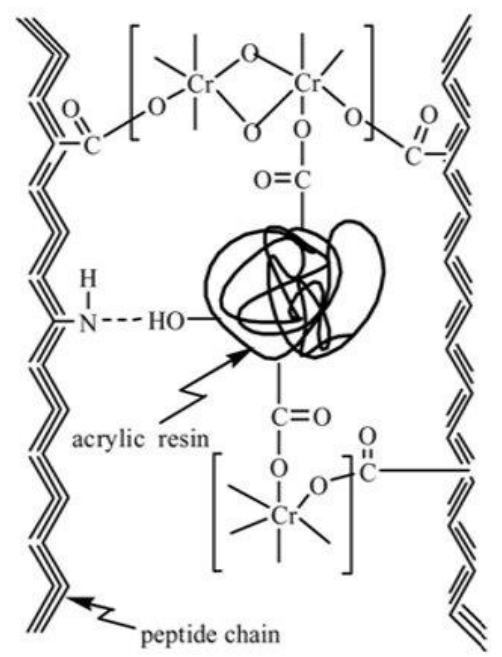

Fig. 3. Interaction of acrylic resin with peptide chain and chromium

The wide use of acrylic acid derivatives is related to the presence of many carboxylic acid side groups that can give tanning property both reacting with multiple chrome centers on the leather and chemical bounding to the collagen groups. Acrylic resin interaction mechanism with chrome tanned leather is presented in Figure 3. Synthetic retanning materials are used for filling and softening, as auxiliaries during fatliquoring and sometimes as replacements of tannins in combination with vegetable extracts. The filling improves the tightness and fineness of the leather grain with mellow surface. The retanning agents play important role in the final degree of leather waterproofness. Melamine- dicyandiamide resin, acrylonitrile resin, styrene maleic copolymer, chestnut can significantly to lower water absorption of leather [17]. Fatliquoring agents are one of the important leather chemicals that have great effect on leather performance. It can penetrate into the interwoven structure of the collagen fibres, prevent the leather fibers from putrefaction, make the fibres stick together and improve their physical and mechanical capabilities [18]. The fatliquoring is the main step in the production of hydrophobic leather. Generally, fatliquoring substances are divided into hydrophobic (emulsified) components and hydrophilic (emulsifying) components.

Multifunction fatliquoring agents can offer more new capabilities for leather. Besides fatliquoring function, they can enhance segment mobility of molecular chain of collagen fibers, and contribute higher level of softness, flexibility, waterproofness, perspiration resistance, etc. [19][20]. Not only waterproofing but also repellent properties to the leather confer silicone derivatives and fluorcarbonated resin. Silicones may be applied from hydro-carbon solvents on the dry leather by dipping or spraying or a silicone emulsion may be applied in the drum on the wet leather by a fatliquoring. Silicones have very high interfacial tensions relative to water and these are not very temperature sensitive. However, silicones are not very effective as solo agents. Fluorocarbons are applied from solvent solutions and have equally high water repellency and also oil repellency [21].

\section{MECHANISM OF WATERPROOFING}

A liquid will wet a surface only if it is of lower surface energy or surface tension than that of the surface. If the surface tension is very much lower than the substrate, spontaneous spreading of the liquid can be observed. If the liquid has a higher surface tension than the substrate, the surface will not be wet and the liquid will bead. Looking closely at a droplet of liquid resting on a surface the contact angle $(\theta)$, formed between the liquid and substrate can be measured. If the contact angle is less than $90^{\circ}$, the liquid has wet the surface. If the contact angle is greater than $90^{\circ}$ the liquid has not wet the surface and the substrate will show hydrophobic nature and waterproofness.

Fluoropolymers and fluorinated chrome complexes are two types of product used to waterproof leather. They act by making the fibres themselves water repellent rather than by filling the interstices. The repellency arises from the presence in the molecule of long fluorocarbon chains, which are inherently chemically inert and hydrophobic.
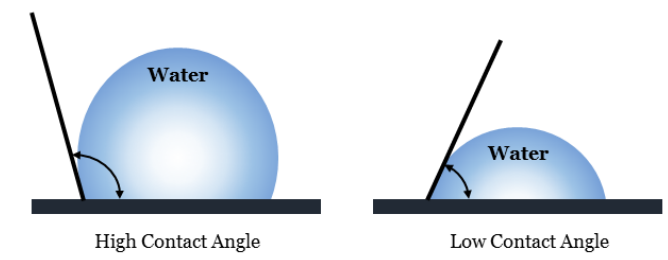

(a)

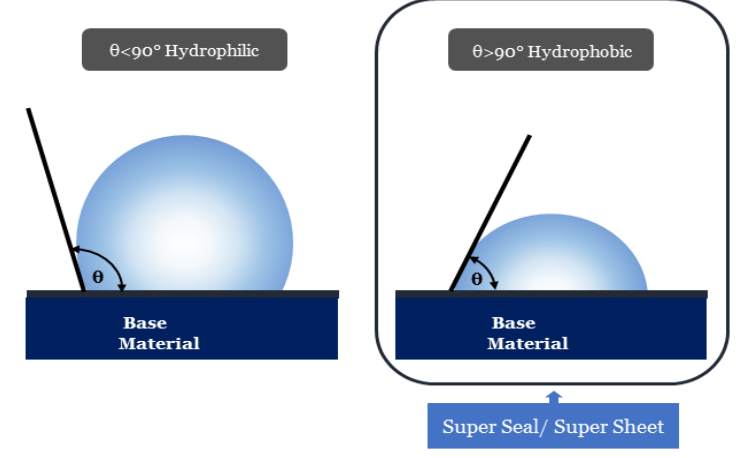

(b)
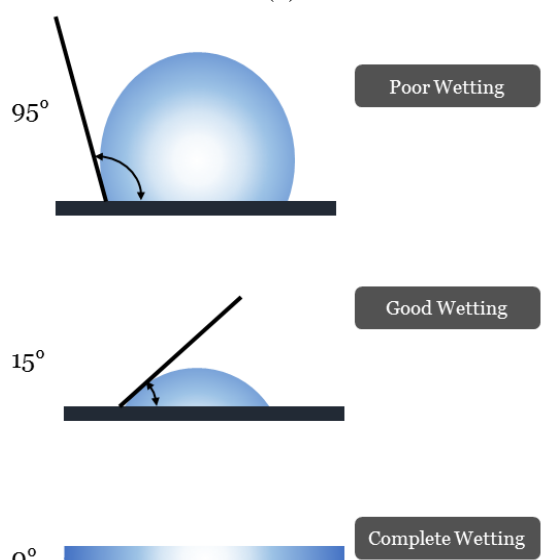

(c)

Fig. 4.a) High and low contact angle, b) Hydrophilic and hydrophobic nature of material and c) Poor, good and complete wetting of material w.r.t. contact angle.

Both types of product derive their fluorination from perfluoro alcohols or acids. Acrylics impart retanning and fatliquoring properties, such as temper and strength. These 
products are compatible with waterproofing fatliquors and other waterproofing materials, such as fluorocarbons or silicones.

\section{EXPERIMENTAL}

\section{A. Materials}

All pieces of cow hides were collected from the Posta hide market, Lalbagh, Dhaka, Bangladesh in three installments. Various chemicals of reputed company (commercial grade) were purchased from Hazaribagh, Dhaka for the production of wet blue, crust and finished leather.

\section{B. Methods}

Use of wet blue as a starting material is not advisable as there would be a possibility of presence of wetting agents, detergents and surfactants that would create problems in

1) Experiment 1 gaining waterproofness. The approaches of the modified process to achieve good waterproof properties are- i) Avoiding the use of surfactants and hydrophilic fatliquors; ii) Use of syntan to achieve the objectives of retanning without affecting the permeability properties; iii) Use of waterproof fatliquors in installment; iv) Thorough washing of the leathers at the end of the processes to remove any neutral salts that might be present; v) Optimization of finishing process to achieve the desired level of waterproofness. The process of crust leather production from domestic cow hides consists of soaking, liming, deliming, bating, pickling, tanning, retanning, dyeing, fatliquoring, fixing and so on. The finishing process started with surface preparation of crust leather, coating with sprayer and ended with ironing or plating.

Tanning, retanning and finishing experiments conducted as described below:

TABLE I: PROCESS OF WET BLUE FOR WATER PROOF LEATHER FROM COW HIDES Chemical percentage $(\%)$ based on raw weight

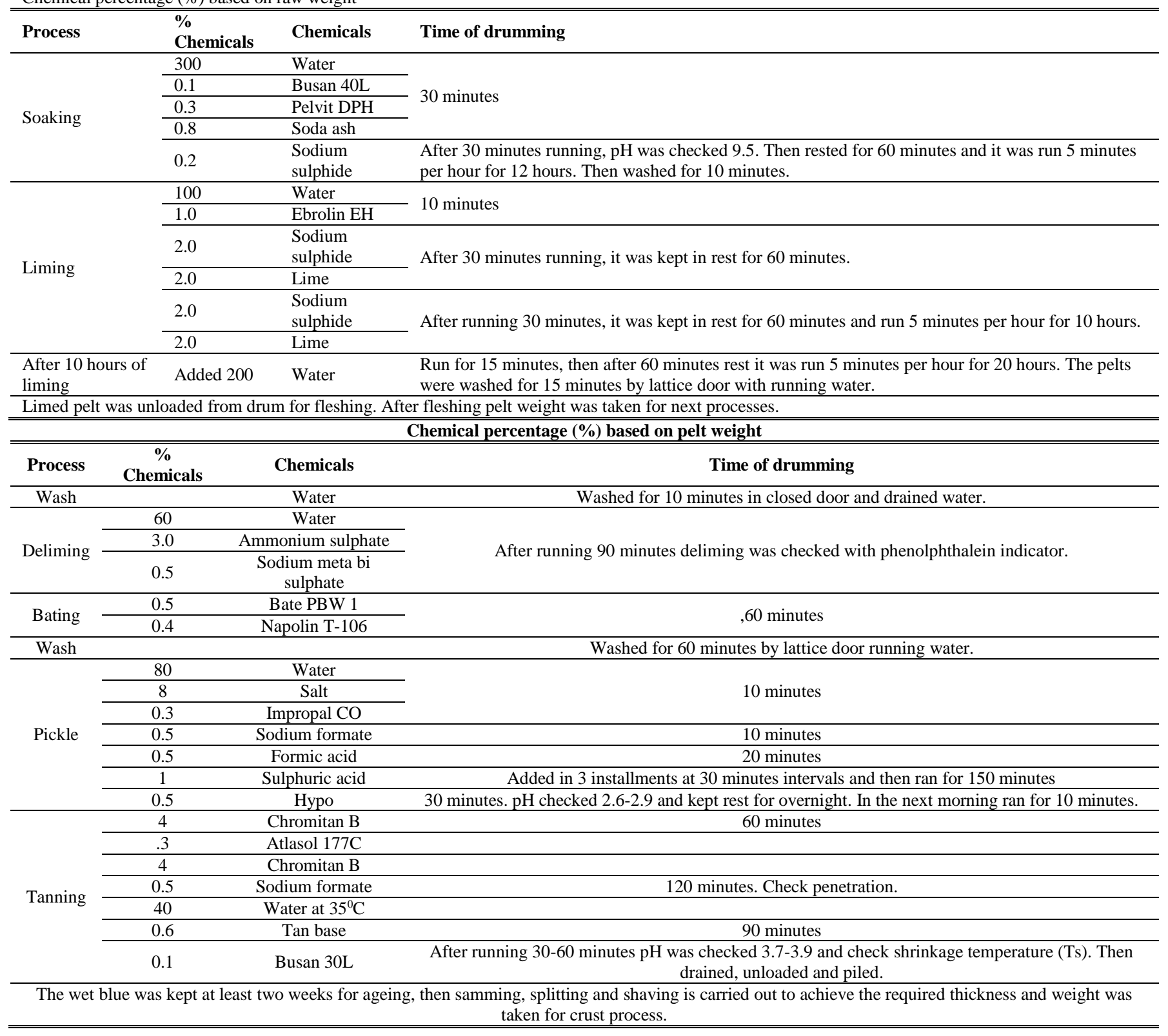


TABLE II: PROCESS OF WATERPROOF CRUST LEATHER FROM WET BLUE COW HIDES

Shaving thickness was maintained for full pieces 1.0-1.1 mm and for sides 1.1-1.2 mm. All chemicals were taken on the basis of shaved weight.

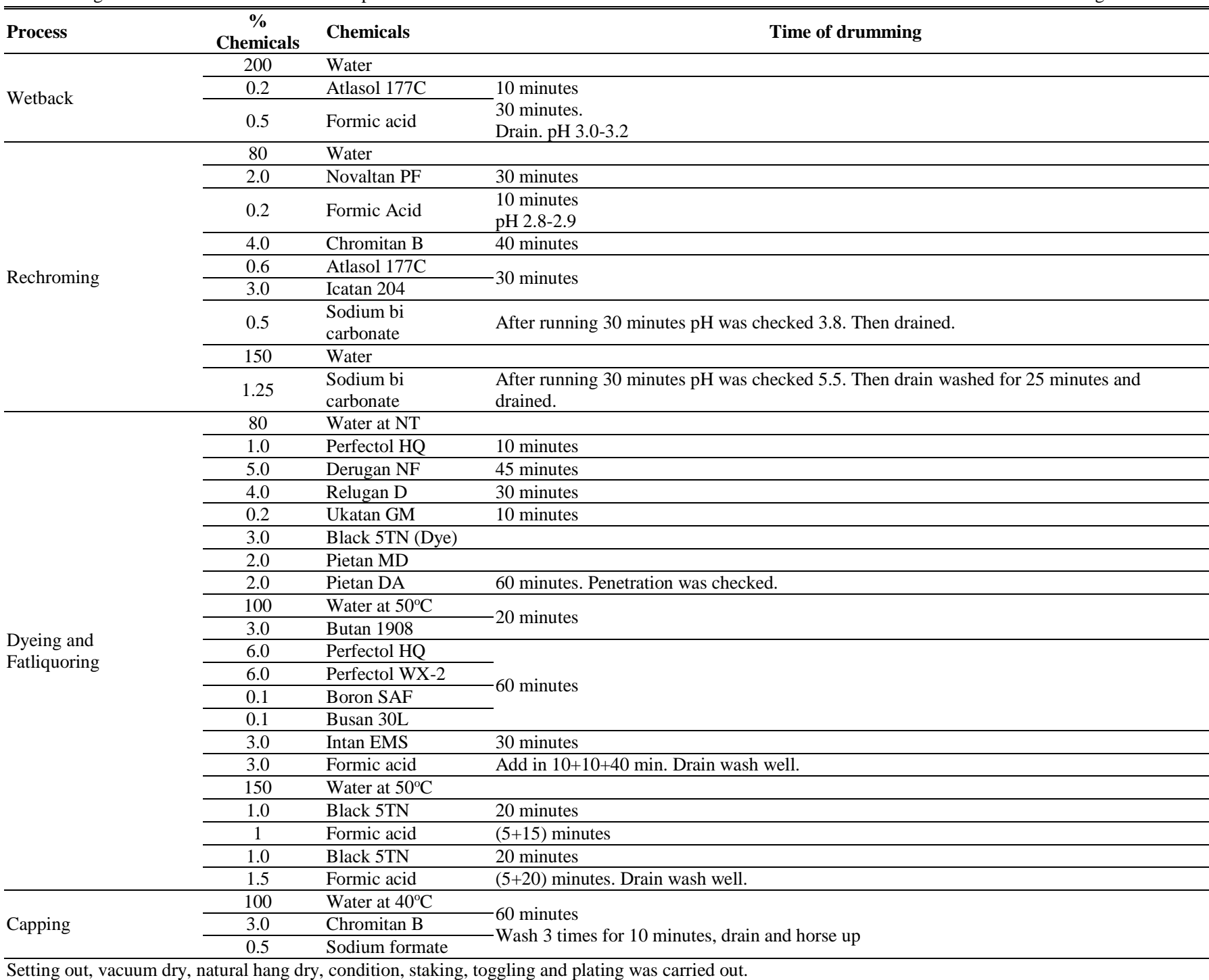

Setting out, vacuum dry, natural hang dry, condition, staking, toggling and plating was carried out.

\begin{tabular}{|c|c|c|c|}
\hline Process & Chemicals & Parts & Remarks \\
\hline \multirow{7}{*}{ Season coating } & Fondo BE & 200 & \multirow{7}{*}{$\begin{array}{l}\text { Spray } 3 \text { Cross } \\
\text { Iron/ Plate with Sand blast (Micro Hair cell) } \\
\text { Spray } 3 \text { Cross }\end{array}$} \\
\hline & Master soft S & 100 & \\
\hline & Resin binder & 200 & \\
\hline & PU Binder & 100 & \\
\hline & Protein binder & 100 & \\
\hline & Pigment & 50 & \\
\hline & Water & 500 & \\
\hline \multirow{3}{*}{ Top coating } & Solvent Lacquer & 100 & \multirow{3}{*}{$\begin{array}{l}\text { Spray } 2 \text { Cross } \\
\text { Roto press } 110^{\circ} \mathrm{C} / 30 \mathrm{Bar}\end{array}$} \\
\hline & Butyl Acetate & 50 & \\
\hline & Silicon & 01 & \\
\hline
\end{tabular}

\section{2) Experiment 2}

TABLE IV: WATER PROOF CRUST FROM WET BLUE COW LEATHER (REF. TABLE I.)

Shaving thickness was for pieces $1.0-1.1 \mathrm{~mm}$. Chemical percentage $(\%)$ based on shaved weight

\begin{tabular}{llll}
\hline \hline Process & \% Chemicals & Chemicals name & Time of drumming \\
\hline \multirow{3}{*}{ Wet back } & 300 & Water at $40^{\circ} \mathrm{C}$ & 10 minutes \\
\cline { 2 - 4 } & +0.3 & Eskatan GLH & 30 and drain wash \\
\hline & +0.3 & Acetic acid & 10 minutes \\
\cline { 2 - 4 } Retanning & Water at $35^{\circ} \mathrm{C}$ & 10 minutes \\
\cline { 2 - 4 } & +2.0 & Black dye liquid & 20 minutes \\
\cline { 2 - 3 } & +0.2 & Formic acid & 20 minutes \\
\cline { 2 - 3 } & +2.0 & Novaltan PF & \\
\cline { 2 - 3 } & +4.0 & Tanesco HN & Chromitan B \\
\cline { 2 - 3 } & & Sodium Formate & 90 minutes \\
\hline \hline
\end{tabular}




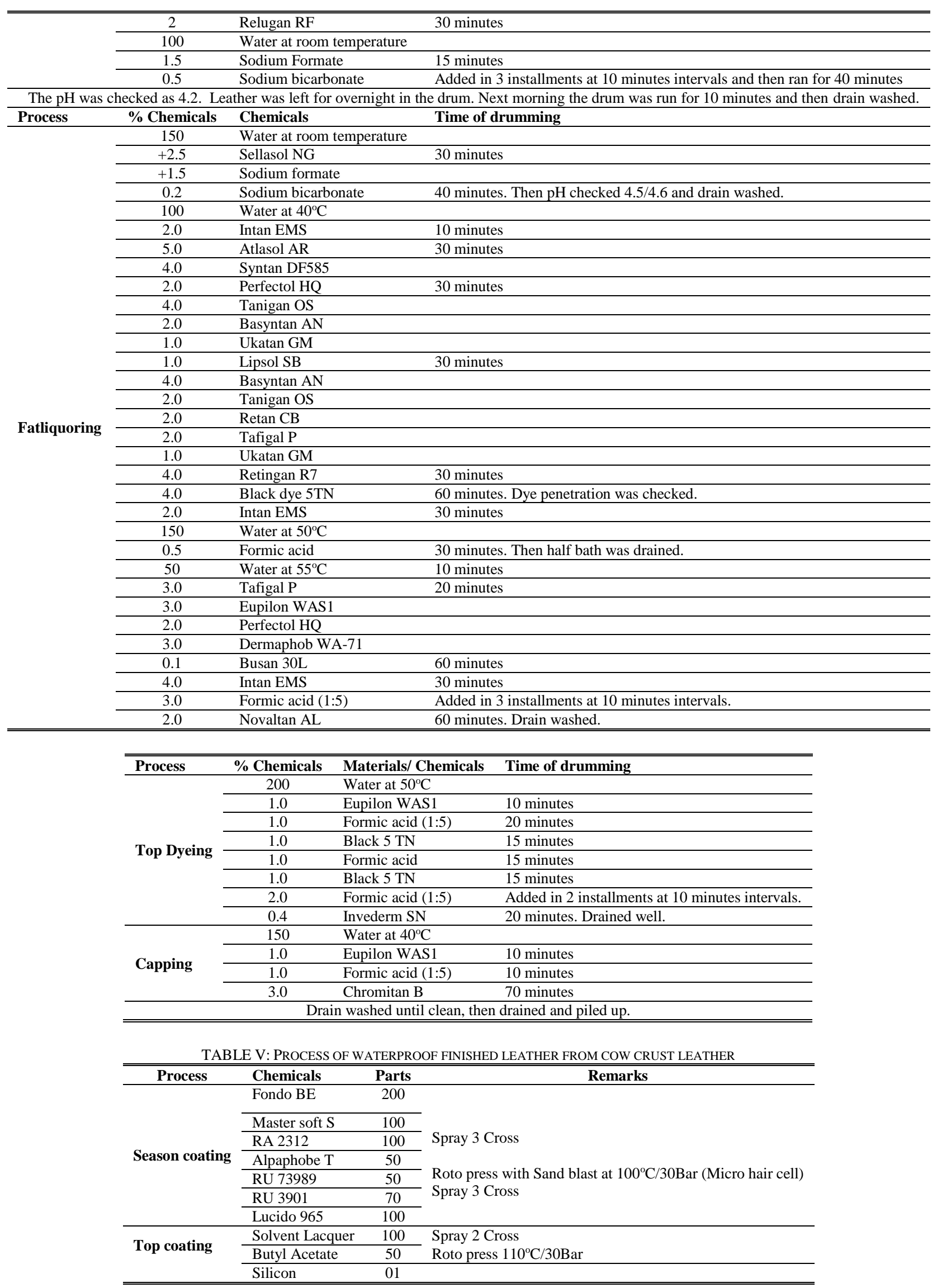




\section{3) Experiment 3}

TABLE VI: PROCESS OF WATERPROOF CRUST LEATHER FROM WET BLUE COW HIDES (REF. TABLE I).

Shaving thickness was maintained 1.0-1.1 mm.All chemicals were taken on the basis of shaved weight.

\begin{tabular}{|c|c|c|c|}
\hline Process & $\begin{array}{c}\% \\
\text { Chemicals } \\
\end{array}$ & $\begin{array}{l}\text { Materials/ } \\
\text { Chemicals } \\
\end{array}$ & Time of drumming \\
\hline \multirow{2}{*}{ Wetback } & 200 & Water & \multirow{2}{*}{60 minutes. Drain. } \\
\hline & 0.3 & Acetic acid & \\
\hline \multirow{9}{*}{ Rechroming } & 100 & Water & \\
\hline & 0.5 & Formic Acid & 30 minutes $\mathrm{pH}$ 2.9-3.0 \\
\hline & 2.0 & Relugan GT 50 & 30 minutes \\
\hline & 5.0 & Chromitan B & \\
\hline & 2.0 & Basyntan AN & 40 minutes \\
\hline & 2.0 & Relugan RF & 40 minutes \\
\hline & 0.5 & Sodium Formate & \\
\hline & +0.5 & $\begin{array}{l}\text { Sodium bi } \\
\text { carbonate }\end{array}$ & $\begin{array}{l}\text { After running } 60 \text { minutes } \mathrm{pH} \text { was checked 4.0. Then run } 5 \text { minute/hour for } \\
\text { overnight. Next day drained. }\end{array}$ \\
\hline & 300 & Water & 10 minutes. Washed and drained. \\
\hline \multirow{6}{*}{ Neutralization } & 100 & Water at $35^{\circ} \mathrm{C}$ & \\
\hline & 2.0 & Butan 7810 & 15 minutes \\
\hline & 0.75 & $\begin{array}{l}\text { Sodium bi } \\
\text { carbonate }\end{array}$ & \\
\hline & 0.75 & Sodium Formate & 45 minutes \\
\hline & 1.0 & Tanigan PAK-S & $\begin{array}{l}30 \text { minutes. } \mathrm{pH} \text { was checked } 5.5 \text {. Then run } 5 \mathrm{~min} / 2 \text { hour for night. Then } \\
\text { drained. }\end{array}$ \\
\hline & 300 & Water & 10 minutes. Drained. \\
\hline \multirow{16}{*}{$\begin{array}{l}\text { Retanning, Dyeing and } \\
\text { Fatliqouring }\end{array}$} & 100 & Water at $40^{\circ} \mathrm{C}$ & \\
\hline & 2.0 & Densodrin CD & 30 minutes \\
\hline & 3.0 & Relugan RE & 40 minutes \\
\hline & 4.0 & Basyntan AN & 30 minutes \\
\hline & 5.0 & Relugan D & \\
\hline & 6.0 & Basyntan AR & \\
\hline & 3.0 & Relugan RV & \\
\hline & 5.0 & Basyntan IS & 10 minutes \\
\hline & 1.0 & Tamol M & \\
\hline & 2.0 & Dye & 60 minutes \\
\hline & 5.0 & Densodrin HP & \\
\hline & 2.0 & Densodrin CD & \\
\hline & 1.0 & Densodrin OF & \\
\hline & 0.3 & Preservative & 60 minutes \\
\hline & 100 & Water at $50^{\circ} \mathrm{C}$ & 10 minutes \\
\hline & 3.0 & Formic Acid & $\begin{array}{l}\text { 2x10+40 minutes. } \mathrm{pH} \text { was checked } 3.6 \text { and then washed with running water and } \\
\text { drained. }\end{array}$ \\
\hline
\end{tabular}

TABLE VII: PROCESS OF WATERPROOF FINISHED LEATHER FROM COW CRUST LEATHER

\begin{tabular}{|c|c|c|c|}
\hline Process & "Materials/ chemicals & Parts & Remarks \\
\hline \multirow{4}{*}{ Adhesion coat } & Dye & 50 & \multirow{4}{*}{1 pass roller coat } \\
\hline & RU 73989 & 100 & \\
\hline & RA 2354 & 50 & \\
\hline & Water & 300 & \\
\hline \multirow{13}{*}{ Season coat } & BI 596 & 50 & \multirow{13}{*}{$\begin{array}{l}\text { Spray } 3 \text { Cross } \\
\text { Roto press with Sand blast at } 100^{\circ} \mathrm{C} / 30 \mathrm{Bar} \text { (Micro hair cell) }\end{array}$} \\
\hline & Water & 500 & \\
\hline & RA 2354 & 50 & \\
\hline & RA 2312 & 100 & \\
\hline & FI 50 & 50 & \\
\hline & AlpaphobeT & 50 & \\
\hline & SFT WR-9 & 50 & \\
\hline & RU 73989 & 50 & \\
\hline & RU 3901 & 70 & \\
\hline & RPU 069 & 30 & \\
\hline & WT 713985 & 20 & \\
\hline & Silicon & 1.5 & \\
\hline & Pigment & $50-100$ & \\
\hline \multirow{6}{*}{ Top coat } & EM finish $\mathrm{KN}$ & 70 & \multirow{6}{*}{$\begin{array}{l}\text { (Nitrocellulose and wax was mixed with water separately and then mixed together to spray) } \\
\text { Spray } 2 \text { Cross, Dry well and Roto press for } 110^{\circ} \mathrm{C} / 30 \text { Bar }\end{array}$} \\
\hline & NEA 635/M & 30 & \\
\hline & Water & 50 & \\
\hline & Wax CF & 5 & \\
\hline & Silicon & 2 & \\
\hline & Water & 50 & \\
\hline
\end{tabular}

\section{RESULTS AND DISCUSSIONS}

During processing, the hides were well opened up in the liming to ensure penetration of the waterproofing chemicals. The hydrophilic products such as salts, dyes and certain types of surfactants (e.g. wetting agents, etc.) were tried to avoid as they have a negative effect on waterproofing. The wet-blue leather was neutralized 
throughout the cross section otherwise the emulsifiers would de-activate at the low $\mathrm{pH}$ and produced incomplete hydrophobing. In the form of a micro emulsion, waterproofing fatliquors ensured deep penetration, access to the fibril level and coating the individual fibrils. The regularity of dyeing, retannage and tannage influenced the distribution of fluorochemical and subsequent performance of waterproofing. The finishing materials and the finishing procedure had been selected according to the condition of the leather, the nature of finish to be produced and the desired quality of the intended waterproof finished leather. The most important things were also considered as the available facilities and the cost involved.

The morphological structure of developed waterproof leather is shown in Figure 5.

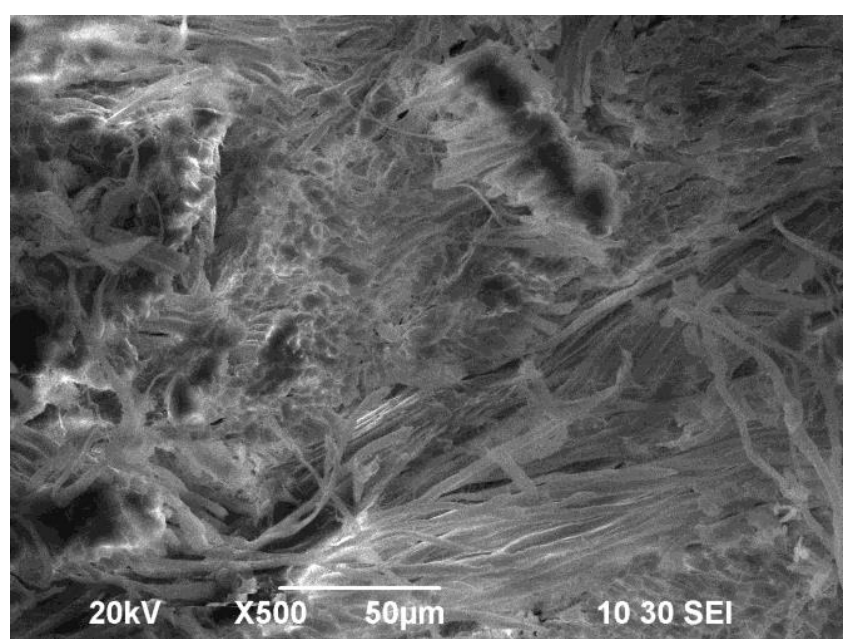

Fig. 5. Scanning Electron Microscopic photograph of developed water proof leather

In order to observe the performance of finishing formulation, an attempt has been made in this work and performed physical tests as per SATRA and IUP methods. For all these tests, sampling and conditioning has been carried out according to international method [22] and [23]. Samples were conditioned at $20^{\circ} \mathrm{C}$ and at $65 \%$ relative humidity for at least 24 hours prior to all measurements.

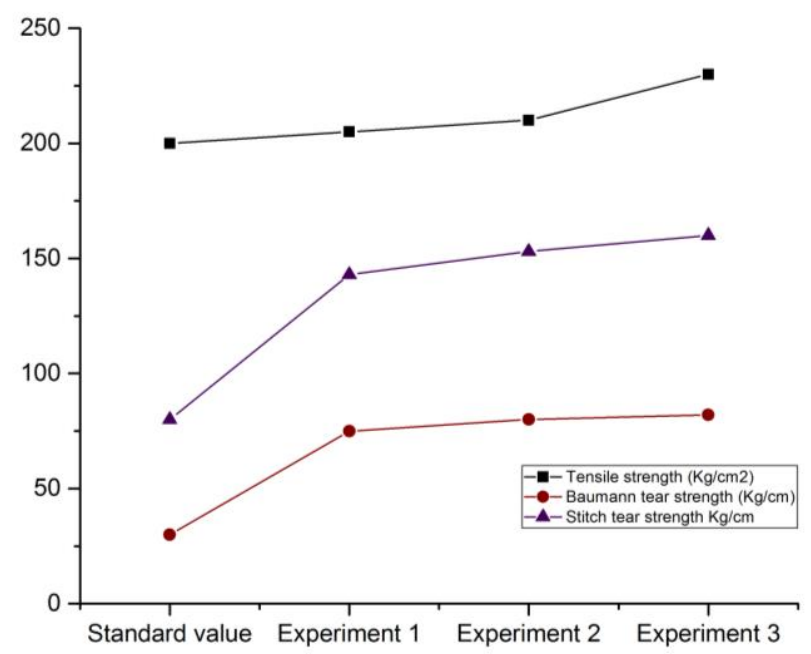

(a)

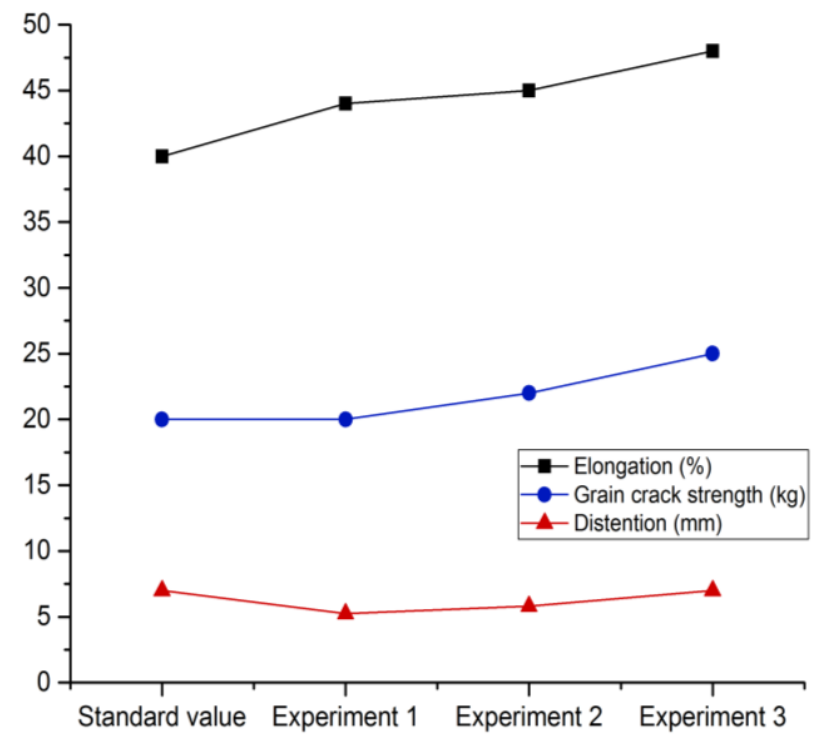

(b)

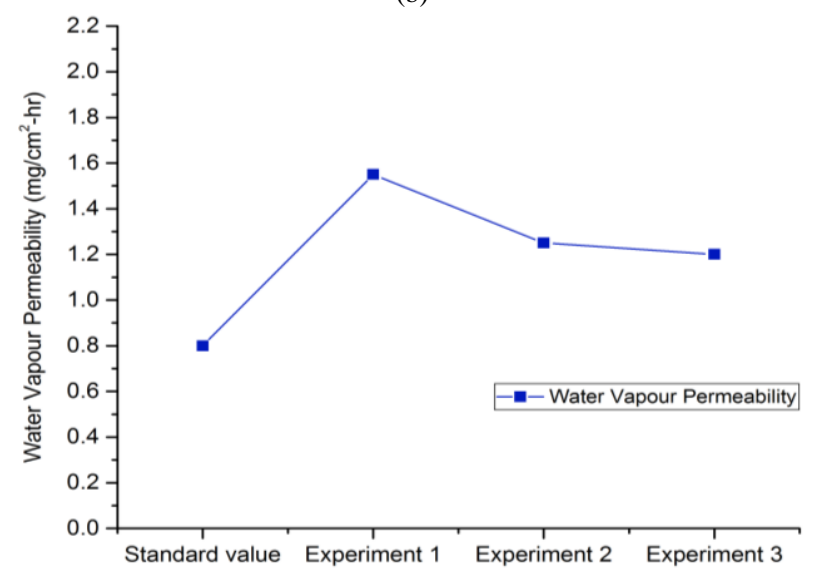

(c)

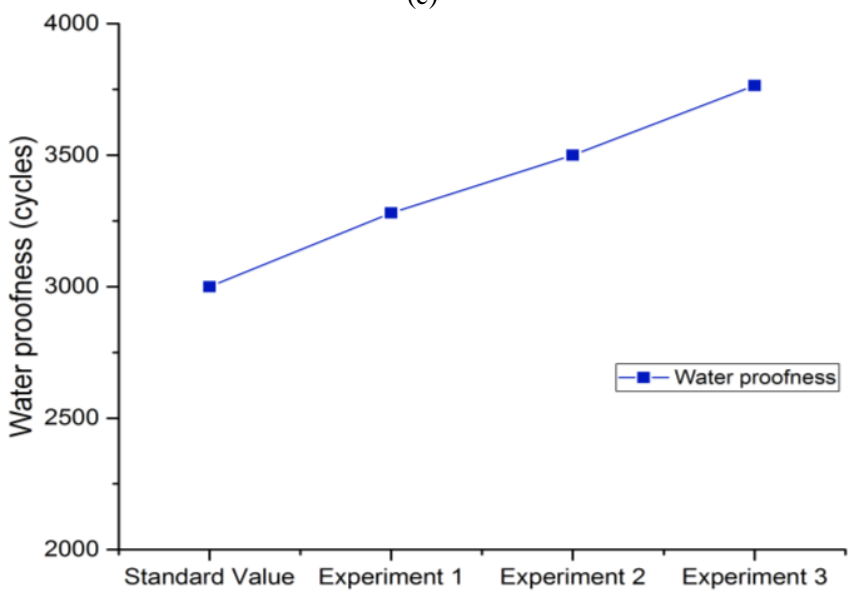

(d)

Fig. 6. Graphical representation of standard value and the readings from Experiment 1, 2 and 3 of a) Elongation, Grain crack strength and Distention, b) Tensile strength, Baumann tear strength and Stitch tear strength, c) Water vapor permeability, d) Waterproofness.

\section{CONCLUSIONS}

Development of modern economic technology for the production of quality waterproof finished leather is very essential to increase export business and national income. Obviously, implementation of the developed economic process will enhance the total finished leather production and reduce crust leather export which will indeed increase national income, boost up job opportunities and engage 
more people in the production line besides the export earnings. In this work, different types of crusting and finishing procedure of traditional technology and latest technology were studied on domestic cow hides. Out of these three experiments all physical properties are higher than the standard value of standard upper leather. However, the waterproofness is highest in case of experiment 3 and water vapour permeability is highest for experiment 1 . It also proves that as waterproofness increased water vapour permeability decreased.

The process of waterproofing leather has been important for high performance footwear many years. Today, however, changing lifestyles and the significance of the leisure sector mean that waterproofing forms a vital part of the high performance leather market.

\section{ACKNOWLEDGEMENTS}

The authors would like to acknowledge the Ministry of Science and Technology, Government of Peoples Republic of Bangladesh for financial support. We also acknowledge and thank to Director, Institute of Leather Engineering and Technology, University of Dhaka for technical support and assistance.

\section{REFERENCES}

[1] S. Dutta, An Introduction tothe Principles of Leather Manufacture, Indian Leather Technologists Association, 2000.

[2] A. D. Covington, Tanning Chemistry-The Science of Leather, Cambridge, RSC Publishing, 2009, p. 592.

[3] W. Herrmann, "Waterproof Leather - Requirements and Technology," Leather International, vol. 9, pp. 56-58, 2006.

[4] R. Beeby, "Making Waterproof Footwear," World Footwear, pp. 1422, 1996.

[5] R. Silva, V. Pinto, F. Freitas and M. Ferreira, "Characterization of Barrier Effects in Footwear.," in Multifuctional Barries for Flexible Structures, S. Duquesne, C. Magniez and G. Camino, Eds., Springer, 2007, pp. 229-268.

[6] A. Gulbinienè, V. Jankauskaitè and V. Urbelis, "The Influence of Laminated Leather Structure on the Water Vapour Absorption and Desorption Behaviour," Materials Science, vol. 14, no. 1, pp. 44-50, 2008.

[7] H. Fan, L. Li, X. Fan and B. Shi, "The Water Vapour Permeability of Leather Finished by Thermally-responsive Polyurethane," Journal of the American Leather Chemists Association, vol. 89, no. 3, pp. 121$125,2005$.

[8] Y. Zhang and L. Wang, "Recent Research Progress on Leather Fatliquoring Agents," Polymer-Plastics Technology and Engineering, vol. 48, no. 3, pp. 285-291, 2009.

[9] L. Liao and Z. Shan, Leather Chemical and Technology, Beijing: Chemical Industry Publishing Company, 2005.

[10] L. Georgieva, K. Krastev and N. Angelov, "dentification of Surface Leather Defects," in Proceedings of the 4th International Conference on Computer Systems and Technologies, New York, USA, 2003.

[11] V. Valeika, J. Sirvaitytè and K. Beleška, Estimation of Chrome-free Tanning Method Suitability in Conformity with Physical and Chemical Properties of Leather Materials.

[12] S. Ahmed, "Leather Finishing and Finishes," Footwear Digest, vol. 35, pp. ii-v, 2003.

13] S. Ahmed and F. Zohra, "Ecological Aspects of Cross linking agents and Their Role in Leather Finishing for the Production of Finished Leather," Leather Age, vol. 2, pp. 67-71, 2011.

[14] E. Howard and N. Oakley, "The Design and Function of Military Footwear: a Review Following Experiences in the South Atlantic," Ergonomics, vol. 27, no. 6, pp. 631-637, 1984.

[15] E.-S. Nashy, A. Hussein and M. Essa, "Retanning Agents for Chrome Tanned Leather Based on Emulsion Nano-particles of Styrene/Butyl Acrylate Copolymers,", New York Science Journal, vol. 3, no. 11, pp. 13-21, 2010.

[16] R. Palop and A. Marsal, "Factor influencing the waterproofing behaviour of Retanning-Fatliquoring Polymers. Part I," Journal of the American Leather Chemists Association, vol. 99, no. 10, pp 409-415, 2004a.

[17] R. Palop and A. Marsal, "Factors Influencing the Waterproofing Behaviour of Retanning-Fatliquoring Polymers. Part II," Journal of the American Leather Chemists Association, vol. 99, no. 11, pp. 461-467, 2004b.

[18] M. Kaussen, "Fatliquoring Agent for Improving the Properties of Furniture and Automotive Leather," Journal of the American Leather Chemists Association, vol. 93, no. 1, pp. 16-21, 1998.

[19] B. Lu, J.-z. Ma, D.-g. Gao, L. Hong, J. Zhang and Q.-n. Xu. "Synthesis and Properties of Modified Rapeseed Oil/Montmorillonite Nanocomposite Fatliquoring Agent.," Journa of Composite Materials, vol. 45, no. 24, pp. 2573-2578, 2011.

[20] B. Lihong, L. Yunjun and Z. Shufen, "Aliphatic Anionic Polyurethane Microemulsion Leather Filling-Retanning Agent," Journal of the Society of Leather Technologists and Chemists, vol 91, no. 2, pp. 73-80, 2007.

[21] Z. Luo, H. Fan, Y. Lu and B. Shi, "Fluorine-containing Aqueous Copolymer Emulsion for Waterproof Leather," Journal of the Society of Leather Technologists and Chemists, vol. 92, no. 3, pp. 107-113, 2008

[22] IUP-2, "Sampling," JSLTC, vol. 84, no. 7, 2000.

[23] IUP-3, Conditioning, Acceptable Quality Standards in the Leather and Footwear Industry-, Vienna: UNIDO, 1996. 